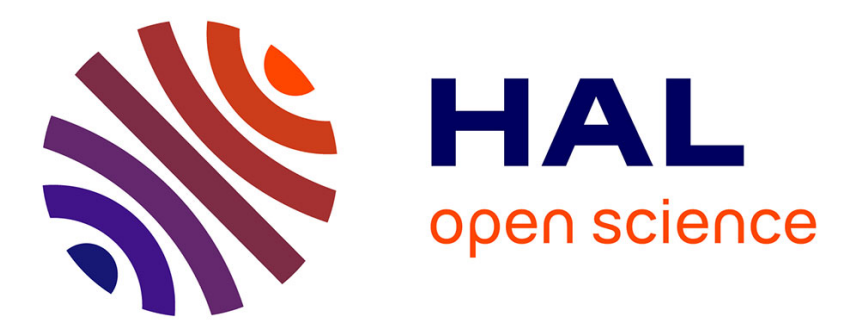

\title{
Environmental management practices: good or bad news for innovations delivering environmental benefits? The moderating effect of market characteristics
}

\author{
Naoufel Mzoughi, Gilles Grolleau, Sanja Pekovic
}

\section{- To cite this version:}

Naoufel Mzoughi, Gilles Grolleau, Sanja Pekovic. Environmental management practices: good or bad news for innovations delivering environmental benefits? The moderating effect of market characteristics. 20. Conférence annuelle de l'EAERE, Jun 2013, Toulouse, France. 21 p. hal-01485479

\author{
HAL Id: hal-01485479 \\ https://hal.science/hal-01485479
}

Submitted on 6 Jun 2020

HAL is a multi-disciplinary open access archive for the deposit and dissemination of scientific research documents, whether they are published or not. The documents may come from teaching and research institutions in France or abroad, or from public or private research centers.
L'archive ouverte pluridisciplinaire HAL, est destinée au dépôt et à la diffusion de documents scientifiques de niveau recherche, publiés ou non, émanant des établissements d'enseignement et de recherche français ou étrangers, des laboratoires publics ou privés. 
Environmental Management Practices: Good or Bad News for Environmental Innovation? The Moderating Effect of Market Characteristics

\begin{abstract}
We examine empirically whether environmental management practices (environmental audits, ISO 14001 standard, etc.) promote (or not) further innovation in the environmental domain. Using a large sample of French firms $(\mathrm{N}=4114)$ and three-stage least square (3SLS) model, we find that environmental management practices influence positively the decision of firms to introduce innovations delivering environmental benefits along both the production and consumption cycles. Nevertheless, this positive relation is moderated by market characteristics. The findings indicate that environmental management practices promote (respectively, promote less) further environmental innovations when the market of their main activity is growing (respectively, uncertain or competitive).
\end{abstract}

Key words: environmental management, environmental innovation, moderation effect.

JEL codes: Q50; O31; L22. 


\section{Environmental Management Practices: Good or Bad News for Environmental Innovation? The Moderating Effect of Market Characteristics}

\section{Introduction}

Environmental management practices (EMPs) have become the cornerstone of environmental policies in several countries. Firms make considerable effort to appear as green, by adopting a large variety of measures, such as the ISO 14001 environmental management system. In response to the proliferation worldwide of such devices, several scholars have examined the possible economic gains of adopting EMPs, such as returns, profitability, added-value, growth, etc. (e.g., Konar and Cohen, 2001; Filbeck and Gorman, 2004; Telle, 2006; Darnall et al., 2008; Cañón-de-Francia and Garcès-Ayerbe, 2009; Clarkson et al., 2010; Nishitani, 2010). Without negating the relevance of these studies, we contend that strictly economic gains are an important part of the story, but only a part of it. In other words, EMPs are likely to deliver other types of benefits that deserve careful attention. ${ }^{1}$ In particular, given that EMPs are mainly intended to improve firms' environmental performance, it is crucial to study their potential to enhance or not further environmental innovation.

A well-known result in the theoretical literature is the superiority of market-based instruments in terms of dynamic efficiency. In other words, these instruments are the best to induce firms to innovate environmentally. Nevertheless, their potential has been less than expected because of several factors such as opposition from industry or real-world implementation diverging from academic models. Interestingly, EMPs possess some features that can impact positively the ability of firms to innovate. First, they offer a high degree of flexibility regarding the way and timing of reaching environmental objectives, which are frequently considered as drivers of environmental innovation. Second, environmental management can be a sign of innovativeness at the firm level which can lead to further innovations in the environmental field (Rogers, 1995). Indeed, a firm's long-term survival may rely more on an overall firm-level innovativeness, that produces dynamic capabilities, which in turn improves the development of innovations (Siguaw et al., 2006). Environmental management can create a climate favorable to innovations by indicating the firm's commitment. Moreover, because they are business-led initiatives, they offer more opportunities for environmental based differentiation on the marketplace. At the same time, critics argue that voluntary environmental management can be just smokescreens that will not necessarily deliver the expected benefits. For instance, Friends of The earth (2002) recently claimed that voluntary approaches, primarily because of their "requirement to find a lowest common denominator position for consensus, stifles rather than stimulating innovation

\footnotetext{
${ }^{1}$ For instance, Grolleau et al. (2012) found empirical evidence to the potential of environmental-related standards to facilitate recruitment among adopting firms.
} 
(emphasis added)." One of the early criticisms of ISO 14001 is that "once again the challenge will be to "beat the inspector" and not to be innovative and adopt new technologies to find long term solutions that lie outside the acceptable boundaries of the inspector" (Kean, 1996 quoted by Marinova and Altham, 2000). In sum, environmental management, if well-designed and implemented can lead to further innovations, but this result is not automatic.

Empirically, only few studies have examined the effects of EMPs on environmental innovation (e.g., Rennings et al., 2006; Frondel et al., 2008; Wagner, 2008) and provide mixed results. Using firm-level data and binary probit regressions, Rennings et al. (2006) have investigated the effects of the EU Environmental Management and Auditing Scheme (EMAS) on technical environmental innovations of 1270 German facilities (all EMAS-validated). They found that EMAS has a positive influence on environmental process and product innovations. Nevertheless, using survey data concerning 849 firms located in nine European countries, Wagner (2008) found that environmental management systems are only associated with process innovations and not product ones. Frondel et al. (2008) applied a recursive bivariate probit model to a sample of 899 German manufacturing firms and found no evidence to the relation between environmental management systems and environmental innovation activities, measured by the facility's changes in production technologies and/or product characteristics to reduce the environmental impacts. Interestingly, Ziegler and Nogareda (2009) have focused on the causal relationship between environmental management systems and technological environmental innovations among a sample of 368 German firms and found that this relationship is obviously not clear. Noteworthy, while environmental innovation is multi-dimensional and embeds different innovation activities aiming to reduce environmental damage, previous studies use in general a single item as a proxy for environmental innovation which may lead to biased or at least partial results. Moreover, as stressed by several scholars (e.g., Aragon-Correa and Sharma, 2003), the effect of exogenous factors, such as market characteristics, has been usually absent in the previous literature.

Given the preceding discussion, the objective of this paper is to test the following hypothesis: the previous adoption of EMPs is associated with increased environmental innovation, ceteris paribus. This empirically-based paper adds content to the existing literature in several ways. First, we distinguish between innovations delivering environmental benefits along the production process and those delivering environmental benefits along the consumption process. Second, since a firm's decision to innovate may depend on market characteristics (e.g., Wang et al., 2011; Wu, 2012), we examine whether the relation between EMPs and environmental innovation is moderated or not by three market characteristics, namely growth, uncertainty and competitiveness (Figure 1). Third, we use a larger sample of firms (4114), compared to previous studies. We merge three firm-level French databases (see Section 2) and control for a detailed set of firm characteristics in order to address 
endogeneity and reverse-causality issues, and properly isolate the potential moderating effect of market characteristics.

[Insert Figure 1 around here]

The remainder of the paper is organized as follows. In the next section, we present data and methods. Section 3 is devoted to estimation results and discussion. Section 4 provides some tentative implications and concludes.

\section{Data and methods}

The data is extracted from three cross-sectional French surveys, namely the Organizational Changes and Computerization's (COI) 2006 survey, Community Innovation's (CIS) 2006-2008 Survey, and the 2003 Annual Firm Survey (EAE). The COI survey is a matched employer/employee survey on organizational changes and computerization conducted between November 2005 and April 2006 by researchers and statisticians from the French institute for statistics and economic studies, the Ministry of labor and the center for labor studies. 17,000 private firms with 10 or more employees from all industries except agriculture, forestry and fishing were surveyed. The questionnaire is selfadministrated and describes work organizational practices in 2006 and changes that have occurred since 2003. The CIS survey was also conducted by the institute for statistics and economic studies over the period 2006-2008, based on the Oslo Manual drawn up by the OECD. Firms with at least 20 employees were asked to answer questions about the type of innovation introduced over the three years period, specific innovation activities carried out in the same period, expenditures and human resources allocated to such activities, and a set of more qualitative information about the sources of information, objectives pursued and hampering factors associated to the innovation process. The EAE Survey is an annual survey conducted by the institute for statistics and economic studies to collect basic data on the structure of surveyed firms such as business activities, size and location. ${ }^{2}$ After the deletion of firms that did not answer all the relevant questions for our study, we are left with 4114 firms with 20 or more employees.

We use two dependent variables denoted PRODENVINNO and CONSENVINNO related to environmental innovations at the production and consumption stages, respectively. PRODENVINNO is computed as follows: firms were asked to indicate whether they have introduced between 2006 and 2008 a product, process, organization or marketing innovation delivering environmental benefits along

\footnotetext{
${ }^{2}$ More details about the design and scope of these surveys are available on www.enquetecoi.net (Survey COITIC 2006-INSEE-CEE/Treatments CEE), http://www.insee.fr/fr/methodes/default.asp?page=sources/sou-enqcommunaut-innovation-cis.htm, and http://www.insee.fr/fr/methodes/default.asp?page=definitions/enqueteannuelle-entreprises.htm.
} 
the production process. Six environmental benefits were presented to them: reduction in raw material use, reduction of energy consumption, reduction of $\mathrm{CO}_{2}$ emissions, substitution of polluting raw materials or hazardous products, reduction of soil, water, or air pollution, and recycling of waste, water, or raw materials. So, we computed the variable PRODENVINNO as the sum of firms' responses for each item. Firms were also asked the same question regarding environmental benefits delivered at the consumption stage. Three items have been proposed: reduction of energy use, reduction of soil, water, or air pollution, and recycling of waste, water, or raw materials. Similarly, we computed the variable CONSENVINNO as the sum of firms' responses for each item. Noteworthy, given that some of the considered environmental benefits delivered at the consumption stage are not relevant for all firms, the effect of EMPs on CONSENVINNO is studied using 2816 firms.

To test the hypothesis that previous adoption of EMPs is associated with increased environmental innovation, ceteris paribus, we use the variable denoted $E M P$ which is a binary variable, equal to 1 if the firm has invested, before 2006, in procedures to regularly identify and reduce its environmental impacts (e.g., preparing environmental audits, setting environmental performance goals, ISO 14001 certification, etc.), and 0 otherwise. Moreover, in order to examine whether market characteristics act as a moderator between EMPs and environmental innovation, we use three variables denoted GROWTH, UNCERTAINTY and COMPETITION. The variable GROWTH is equal to 1, 2 or 3, depending on whether the market of the main activity of the firm got down, is steady, or grown, respectively, since 2003. UNCERTAINTY (respectively, COMPETITION) is a dummy variable, equal to 1 if the firm has been affected very strongly or strongly by market uncertainty (respectively, the entry of new competitors) since 2003 , and 0 otherwise.

Furthermore, in order to control for firm-level heterogeneity, we include in our analysis a set of firms' characteristics likely to influence environmental innovation. First, since it is generally considered that large firms may gain more from scale economies associated with innovations, compared to smaller ones (Nakamura et al., 2001; Grolleau et al., 2007), we include the variable SIZE corresponding to the number of employees. Second, firms belonging to a holding group may be better informed and bear less risk in investing in environmental innovations (del Río González, 2009; Pekovic, 2010). Hence, we include a dummy variable denoted HOLDING taking the value of 1 when the firm belongs to a holding and 0 otherwise. Third, since more profitable firms are more likely to engage in environmental innovation activities, we introduce in estimation firms' profit in 2003 (PROFIT). Fourth, cutting costs may also push firms to introduce an environmental innovation (Grolleau et al., 2007; Horbach, 2008). Thus, we add the variable CUTTING_COSTS corresponding to the importance of cutting costs within the firm, on a scale ranging from 1 (very low) to 4 (very high). Fifth, since quality standards have been proved to create an environment that supports innovation activities (Pekovic and Galia, 2009; see also Nakamura et al., 2001), we include a dummy variable denoted $Q S$, equal to 1 if the firm has adopted 
the ISO 9000 standard in 2003, and 0 otherwise. Sixth, environmental innovation may be enhanced by research and development activities (Jaffe and Palmer, 1997). This effect is tested using the variable $R \& D$ which is equal to 1 if the firm collaborated with private businesses or laboratories, the National Centre for Scientific Research, universities or other public bodies in research and development activities in 2003. Seventh, customer requirements have been found to be an important source for environmental innovations, particularly with regard to products with improved environmental performance and process innovations that increase material efficiency, reduce energy consumption and waste and the use of dangerous substances (e.g., Foster and Green, 2002). Moreover, adopting environmental innovation may help a firm to serve a growing market of environmentally informed customers and command a price premium (Porter and Van Der Linde, 1995a, 1995b). Hence, we introduce a binary variable (CUSTOMER), equal to 1 if the firm used tools to study customers' expectations, behaviour or satisfaction in 2003, and 0 otherwise. Eight, environmental innovation activities may differ across sectors. Based on the N36 sector classification created by the French institute for statistics and economic studies, we include eleven sectoral dummy variables representing the following sectors: agrifood, consumption goods, cars and equipment, intermediate goods, energy, construction, commercial, transport, financial and real-estate activities, business services and individual services.

\section{Econometric model}

According to several studies (e.g., Nakamura et al., 2001; Grolleau et al., 2007; Arimura et al., 2008) the considered firms' characteristics are likely to influence the decision to adopt EMPs. In other words, the same unobservable factors may have an impact on both environmental innovation and EMPs, leading to an endogeneity bias. In order to address this issue, we apply a three-stage least square model (3SLS). The first step predicts the values of each endogenous variable on all the exogenous regressors. In the second step, the model uses the predicted values of EMPs under various market situations to estimate environmental innovation. The residuals are then used to obtain an estimate of the covariance matrix of the error terms of the three equations. In the third step, the estimate of the cross-equation correlation matrix is used as a weighting matrix to calculate the generalized least square estimator (GLS). The last two steps are iterated over the estimated disturbance covariance and parameter estimates until the parameter estimates converge. ${ }^{3}$ The five equations are

\footnotetext{
${ }^{3}$ One may argue that the 3 SLS model is not appropriate with a dummy endogenous regressor (here, EMP). However, Angrist and Krueger (2001) show that using a probit or logit to generate first-stage predicted values in applications with a dummy endogenous regressor may harm results. In fact, in 2SLS or 3SLS, consistency of the second-stage estimates does not influence the first-stage functional form (Kelejian, 1971). Hence, the authors
} 
jointly estimated for each explanatory variable using maximum likelihood. We consider the following 3SLS model:

$$
\left\{\begin{array}{l}
Y_{1}^{*}=\alpha_{1}+\beta_{1} X_{1}+\delta_{1} Z_{1}+\mu_{1} \\
Y_{2}^{*}=\alpha_{2}+\beta_{2} X_{2}+\delta_{2} Z_{2}+\mu_{2} \\
Y_{3}^{*}=\alpha_{3}+\beta_{3} X_{3}+\delta_{3} Z_{3}+\mu_{3} \\
Y_{4}^{*}=\alpha_{4}+\beta_{4} X_{4}+\delta_{4} Z_{4}+\mu_{4} \\
Y_{5}^{*}=\alpha_{5}+\beta_{5} X_{5}+\gamma_{1} Y_{1}+\gamma_{2} Y_{2}+\gamma_{3} Y_{3}+\gamma_{4} Y_{4}+\mu_{5}
\end{array}\right.
$$

$Y_{1}^{*}, Y_{2}^{*}, Y_{3}^{*}, Y_{4}^{*}$ and $Y_{5}^{*}$ are latent variables influencing the probability that the firm implements EMPs, EMPs when the market of its main activity is growing, EMPs when the market is uncertain, EMPs when the market is strongly competitive, and innovates in the environmental field, respectively. $X_{1}, X_{2}, X_{3}, X_{4}$ and $X_{5}$ are the vectors of exogenous variables. Noteworthy, following Ozer-Balli and Sorensen (2010), in a regression with interaction terms we include also the main terms (in order to isolate effects of market situations) and use demeaned interaction terms. $Z_{1}, Z_{2}, Z_{3}$ and $Z_{4}$ represent the instrumental variables that guarantee the identification of the model and helps estimating correlation coefficients (Maddala, 1983). Indeed, in order to identify the three-stage least square model, we need additional variables that explain the probability of adopting EMPs in isolation and under various market situations, but are not correlated to the error term of the environmental innovation equation. Due to data limitations, it is difficult to find an appropriate instrument which has to explain well the EMPs adoption (relevance) but has to be independent of the error term (validity). In what follows, we discuss the quality of the instruments providing both qualitative arguments and formal test of relevance and validity of the suggested instruments. In our case, $Z_{1}$ captures whether the firm relocates a part of its business (RELOCATION) and share of exports in total sales (EXPORT). The choice of variable RELOCATION is based on the fact that achieving scale economies by applying the same standard in all production units and not being suspected to relocate in pollution havens can drive firms to adopt environmental practices (Grolleau and Mzoughi, 2005; Grolleau et al., 2012). The use of the variable EXPORT may be explained by the fact that information asymmetry about environmental attributes is generally more important when agents evolve in different institutional environments (King and Lenox, 2001). From a signalling perspective, environmental practices can provide information on the general capability of a firm to meet the environmental expectations of customers and thus make unobservable characteristics more public (Grolleau et al., 2007). At the same

confirm that using a linear regression for the first-stage estimates generates consistent second-stage estimates even with a dummy endogenous variable. 
time, De Marchi and Grandinetti (2012, see also references therein) found strong empirical support that exports do not explain the adoption of eco-innovations in the context developed countries. We believe that these two variables do not influence a priori the potential of firms to introduce environmental innovations. We are aware that these instruments are not perfect, but are suitable ones. As it is common with such models, we judge the quality of instrumental variables using the StockYogo (2005) and Sargan statistics. Furthermore, considering that EMP is endogenous, market situations exogenous, and, $Z_{1}$ a valid instrument for environmental management practices, interaction between market situations and $Z_{1}$ will be a valid instrument for environmental practices under different market situations (Ozer-Balli and Sorensen, 2010). $Z_{2}, Z_{3}$ and $Z_{4}$ are created similarly. $\beta_{1}$ to $\beta_{5}, \gamma_{1}$ to $\gamma_{5}, \delta_{1}$ to $\delta_{5}$ are slope coefficients to be estimated. Finally, $\alpha_{1}$ to $\alpha_{5}$ and $\mu_{1}$ to $\mu_{5}$ are the intercepts and the disturbance terms for the five equations, respectively.

Finally, one may argue that it is improved environmental innovations which allow firms to adopt EMPs. In order to overcome this reverse-causality issue, our estimations are performed using lagged information. While the implementation of EMPs (respectively, market characteristics) is observed before 2006 (respectively, since 2003), environmental innovation is observed between 2006 and 2008 . The variables used in estimation, their definitions and sample statistics are presented in Tables 1 and 2. No problem of multicollinearity has been detected (Appendices A and B).

[Insert Tables 1 and 2 around here]

\section{Results}

In order to check the validity of our instrumental variables, we run a 2SLS model (not reported) using the ivreg2 command under STATA which provides the Stock-Yogo (2005) and Sargan statistics usable in such cases. The Stock-Yogo statistics show that our instrumental variables are satisfying, since $F(20,1490)$ is equal to 22.99 and $F(20,1021)$ equal to 14.20 , for innovations delivering environmental benefits in the production and consumption stages, respectively. The critical value with maximum bias of the IV estimator relative to OLS of 0.10 is 19.93 for both models. In addition, the Sargan test fails to reject the null of validity of instruments ( $p$ value $=0.1432$ and $p$ value $=0.9726$ for innovations delivering environmental benefits in the production and consumption stages, respectively).

Estimation results are presented in Tables 3 and 4. Looking at R2 in both tables, we may conclude that our model is well identified. We first present the estimation results regarding the factors influencing firm's decision to adopt EMPs in isolation and under various market characteristics (columns 2, 3, 4, and 5).

[Insert Tables 3 and 4 around here] 
As expected, the variables corresponding to firm size, belonging to a holding group, profit, cost cutting importance, adoption of the ISO 9000 standard, research and development, and customers' satisfaction are significant predictors for the adoption of EMPs. Firm's probability to adopt EMPs decreases with market's uncertainty. Similarly to the findings of other scholars (e.g., Delmas and Pekovic, 2012), the latter results vary according to the market characteristic. For instance, when the market of the main activity of the firm is growing, the adoption of EMPs is driven positively (negatively) by firm's size and profit (the adoption of the ISO 9000 standard). When the market is uncertain, the adoption of EMPs is positively (negatively) influenced by firm's size, cost cutting importance, and research and development activities (belonging to a holding group, profit, and market growth). Finally, when market is highly competitive, our findings indicate that adoption of EMPs is positively (negatively) related to profit and cost cutting importance (adoption of the ISO 9000 standard, research and development activities, and market growth).

We now turn to the results regarding the hypothesis that previous adoption of EMPs is associated with increased environmental innovation, ceteris paribus. First, our findings indicate that EMPs impact positively the introduction of innovations delivering environmental benefits in both the production and consumption stages, since the coefficients of EMP are positive and statistically significant at the $1 \%$ level (column 1 in Tables 3 and 4). Second, the adoption of EMPs influences environmental innovation differently according to market characteristics. When the market of the main activity of the firm is growing, the adoption of EMPs improves environmental innovation at the production stage, but the effect is not significant at the consumption stage. This result might suggest that when the market is growing, environmental innovation is mainly driven by private concerns, that is, firms may innovate in the environmental field in order to reduce their compliance costs, since pollution may be considered as a manifestation of economic waste (Porter, 1995b). Another plausible explanation of this result is that, from consumers' viewpoint (and society as a whole), firms' image might be more associated with its own environmentally-friendly activities, rather than proposing to consumers products with high environmental performance for them. Moreover, when the market is uncertain or highly competitive, the interaction term is negative. But this result does not automatically imply that adoption of EMPs influences negatively firm's decision to introduce innovations delivering environmental benefits in both the production and consumption stage. Indeed, to fully evaluate the effect of EMPs, we must consider both the direct effect and the interaction effect. Even in uncertain markets, the total net effect of EMPs is positive. It is smaller (6.41-0.61 for production innovations, for example) in uncertain markets. Even in uncertain markets, the results show that firms using EMPs do more environmental innovation than firms that do not use EMPs.

In other words, when firms are confronted to uncertainty or competition, they can judge EMPs as sufficient and subsequently reduce investment in the environmental field and choose to compete on 
dimensions other than environmental ones. Additionally, firms facing highly uncertain or competitive market may fear more that the adoption of environmental innovation in such circumstances could be perceived as the wrong decision. Therefore, as suggested by Martin-Tapia et al. (2008), in highly uncertain and competitive market, firms behave in a more conservative way. These findings are consistent with those obtained by Wang and Chen (2010) who indicate that the total value that can be potentially generated from specific innovations is likely to be lower under market dynamism or uncertainty. In summary, the evidence presented supports previous studies that stress the relevance of considering the general business environment when examining environmental practices and firm performance outcomes (e.g. Martin-Tapia et al., 2008).

Finally, our model provides also findings regarding the determinants of environmental innovations in both the production and consumption stages. Estimation results indicate that environmental innovation at the production stage is positively (negatively) influenced by market characteristics such as uncertainty and competition, and client satisfaction (belonging to a holding group, profit, adoption of the ISO 9000 standard, and research and development activities). Similarly, environmental innovation at the consumption stage is positively (negatively) influenced by market characteristics such as uncertainty and competition (belonging to a holding group, profit, cost cutting importance, adoption of the ISO 9000 standard, and research and development activities, and market growth).

\section{Conclusion}

Let us return to our main question: does EMPs constitute good or bad news for environmental innovation? Our empirical analysis supports a 'yes' answer but not an unconditional 'yes'. Indeed, we found that environmental management practices influence positively the decision of firms to introduce innovations delivering environmental benefits along both the production and consumption cycles, but this positive relationship is strongly moderated by market characteristics. The findings indicate that environmental management practices promote (respectively, promote less) further environmental innovations when the market of their main activity is growing (respectively, uncertain or competitive). Interestingly, these results can provide a plausible explanation for the puzzle stressed in the literature review regarding the effects of EMPs on environmental innovations. A direct policy implication of our findings implies that encouraging all firms to adopt EMPs regardless of market characteristics will not automatically lead to further environmental innovation. Consequently, if the goal is to foster environmental innovation a 'one-size-fits-all' policy in favor of EMPs is likely to be inadequate, notably because it does not take account the effect of market characteristics. According to our findings, policies that can offer the 'best return on investment' regarding dynamic efficiency are those that target firms for which market is growing. When market characteristics are uncertain or competitive, promoting environmental innovation may require alternative strategies. So, managers also need to consider market characteristics in which their firm operates and adjust their environmental strategies 
as these characteristics change. Our study also constitutes an appeal to consider more systematically the effect of market characteristics when examining the promises of EMPs.

This study is subject to a number of limitations and some of them are natural avenues for future research. First, our research is conducted using a sample of French firms. We do believe that national context might affect our results. Second, cross-sectional data may have introduced common method bias. We took several steps to address this potential problem, including the lagged information. Nevertheless, future research should aim to work on panel data in order to check the validity of the results. Third, future research should expand the range of environmental performance outcomes studied such as the estimated expenses related environmental innovations. Notwithstanding these limitations, the evidence presented in this paper highlights the complex relationship between environmental management practices and environmental innovations. 


\section{References}

Angrist, J.D., Krueger, A.B., 2001. Instrumental Variables and the Search for Identification: From Supply and Demand to Natural Experiments. Journal of Economic Perspectives 15(4), 69-85.

Aragon-Correa, J.A., Sharma, S., 2003. A Contingent Resource-Based View of Proactive Corporate Environmental Strategy. Academy of Management Review 28 (1), 71-88.

Arimura, T.H., Hibiki, A., Katayama, H., 2008. Is a Voluntary Approach an Effective Environmental Policy Instrument? A Case for Environmental Management Systems. Journal of Environmental Economics and Management 55, 281-295.

Cañón-de-Francia, J., Garcés-Ayerbe, C., 2009. ISO 14001 Environmental Certification: A Sign Valued by the Market?. Environmental and Resource Economics 44, 245-262.

Clarkson, P., Li, Y., Richardson, G., Vasvari, F., 2010. Does it Really Pay to be Green? Determinants and Consequences of Proactive Environmental Strategies. Journal of Accounting and Public Policy doi:10.1016/j.jaccpubpol.2010.09.013.

Darnall, N., Henriques, I., Sadorsky, P., 2008. Do Environmental Management Systems Improve Business Performance in the International Setting? Journal of International Management 14(4), 364-376.

Del Rio Gonzalez, P., 2009. The Empirical Analysis of the Determinants for Environmental Technological Change: A Research Agenda. Ecological Economics 68, 861-878.

Delmas, M., Pekovic., S., 2012. Sustainability and Market Conditions: The Resource Efficiency Paradox. Working paper, Institute of the Environment and Sustainability, UCLA.

De Marchi V., Grandinetti, R., 2012. Who are the green innovators? An empirical analysis of firm's level factors driving environmental innovation adoption. Paper to be presented at the DRUID 2012, June 19 to June 21, Copenhagen, Denmark, http://druid8.sit.aau.dk/acc_papers/b47o2q6ffyodrsujybnpy63hpt2u.pdf.

Filbeck, G., Gorman RF., 2004. The Relationship between Environmental and Financial Performance of Public Utilities. Environment and Resources Economics 29, 137-157.

Foster, C., Green, K., 2002. Environmental Innovation in Industry: The Importance of Environmentally-Driven Users. International Journal of Environmental Technology and Management 2(4), 303-314.

Friends of The Earth, 2002. Undemocratic, Ineffective and Inherently Weak - The Voluntary Approach. http://www.foe.co.uk/resource/briefings/voluntary_approach.pdf.

Frondel, M., Horbach, J., Rennings, K., 2008. What Triggers Environmental Management and Innovation? Empirical Evidence for Germany. Ecological Economics 66(1), 153-160.

Grolleau, G., Mzoughi, N., 2005, Overcomplying For Profit: A Note. Environmental Economics and Policy Studies 6(4), 267-269.

Grolleau, G., Mzoughi, N., Pekovic, S., 2007. Chemical Firms' Registration for the Responsible Care Program and the ISO 14001 Standard: A Comparative Approach. Economics Bulletin 12, 1-13. 
Grolleau, G., Mzoughi, N., Pekovic, S., 2012. Green Not (only) for Profit: An Empirical Examination of the Effect of Environmental-Related Standards on Employees' Recruitment. Resource and Energy Economics 34(1), 74-92.

Horbach, J., 2008. Determinants of Environmental Innovation - New Evidence from German Panel Data Sources. Research Policy 37, 163-173.

Jaffe, B. A., Palmer, K., 1997. Environmental Regulation and Innovation: A Panel Data Study. The Review of Economics and Statistics 79(4), 610-619.

Kelejian, H.H., 1971. Two-Stage Least Squares and Econometric Systems Linear in Parameters but Nonlinear in the Endogenous Variables. Journal of the American Statistical Association 66, 373374.

King, A., Lenox, M., 2001. Industry Self-Regulation without Sanctions: The Chemical Industry's Responsible Care Program. Academy of Management Journal 43(4), 698-716.

Konar, S., Cohen, M.A., 2001. Does the Market Value Environmental Performance?. Review of Economics and Statistics 83(2), 281-289.

Maddala, G.S., 1983. Limited-Dependent and Qualitative Variables in Econometrics. Cambridge University Press.

Marinova, D., Altham, W., 2000. ISO 14001 and the Adoption of New Technology, in: Hillary, R., (Ed.), ISO 14001: Case Studies and Practical Experiences. Sheffield, Greenleaf Publishing, pp. 251-260.

Martin-Tapia, I., Aragon-Correa, J.A., Senise-Barrio, M.E., 2008. Being Green and Export Intensity of SMEs: The Moderating Influence of Perceived Uncertainty. Ecological Economics 68 (1-2), 56-67.

Nakamura, M., Takahashi T., Vertinsky, I., 2001. Why Japanese Firms Choose to Certify: A Study of Managerial Responses to Environmental Issues. Journal of Environmental Economics and Management 42, 23 - 52.

Nishitani, K., 2010. An Empirical Analysis of the Effects on Firm's Economic Performance of Implementing Environmental Management Systems. Environmental and Resources Economics DOI 10.1007/s10640-010-9404-3.

Ozer-Balli, H., Sorensen, B.E., 2010. Interaction Effects in Econometrics. Discussion Paper 7929, Centre for Economic Policy Research.

Pekovic, S., 2010. The Determinants of ISO 9000 Certification: A Comparison of the Manufacturing and Service Sectors. Journal of Economic Issues 44(4), 895-914.

Pekovic, S., Galia, F. 2009. From Quality to Innovation: Evidence from Two French Employer Surveys. Technovation 29, 829-842.

Porter, M., Van Der Linde, C., 1995a. Toward a New Conception of the EnvironmentCompetitiveness Relationship. Journal of Economic Perspectives 9(4), 97-118.

Porter, M., Van Der Linde, C., 1995b. Green and Competitive: Ending the Stalemate. Harvard Business Review 73(4), 120-134. 
Rennings, K., Ziegler, A., Ankele, K., Hoffmann, E., 2006. The Influence of Different Characteristics of the EU Environmental Management and Auditing Scheme on Technical Environmental Innovations and Economic Performance. Ecological Economics 57(1), 45-59.

Rogers, E.M., 1995. Diffusion of Innovations, fourth ed. Free Press, New York.

Siguaw, J.A., Simpson, P.M., Enz, C.A., 2006. Conceptualizing Innovation Orientation: A Framework for Study and Integration of Innovation Research. Journal of Product Innovation Management 23(6), 556-574.

Stock, Yogo, M., 2005, Testing for Weak Instruments in IV Regression, in Andrews, D.W. K., Stock, J.H., (eds.), Identification and Inference for Econometric Models: Essays in Honor of Thomas Rothenberg, Cambridge University Press: Cambridge, 80-108.

Telle, K., 2006, It Pays to Be Green - A Premature Conclusion?, Environmental and Resources Economics, 35, 195-220.

Wagner, M., 2008. Empirical Influence of Environmental Management on Innovation: Evidence from Europe. Ecological Economics 66(2-3), 392-402.

Wang, H., Chen, W.R., 2010. Is Firm-Specific Innovation Associated with Greater Value Appropriation? The Roles of Environmental Dynamism and Technological Diversity. Research Policy 39(1), 141-154.

Wang, L, Yeung, J.H.Y., Zhang, M., 2011. The Impact of Trust and Contract on Innovation Performance: The Moderating Role of Environmental Uncertainty. International Journal of Production Economics 134(1), 114-122.

Wu, J., 2012. Technological Collaboration in Product Innovation: The Role of Market Competition and Sectoral Technological Intensity. Research Policy 41, 489-496.

Ziegler, A., Nogareda, J., 2009. Environmental Management Systems and Technological Environmental Innovations: Exploring the Causal Relationship. Research Policy 38(5), 885-893. 
Figure 1: The Relationship between EMPs and Environmental Innovation: The Moderating Effect of Market Characteristics

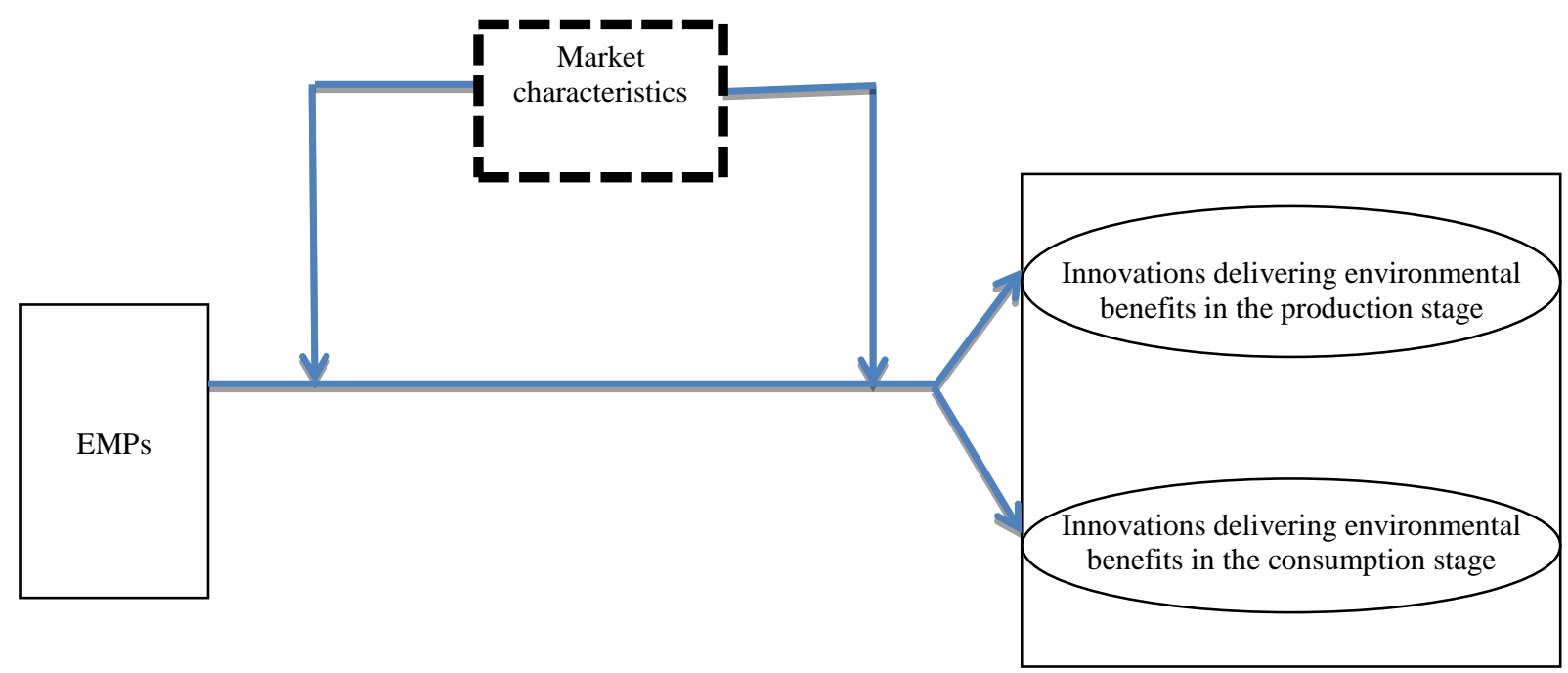


Table 1: Definition of variables and sample statistics (sample for environmental innovations in the production stage)

\begin{tabular}{|c|c|c|c|c|c|}
\hline Variable & Description & Mean & SD & Min & Max \\
\hline \multicolumn{6}{|l|}{ Dependent variable } \\
\hline PRODENVINNO & $\begin{array}{l}\text { The firm has introduced between } 2006 \text { and } 2008 \text { a product, process, } \\
\text { organization or marketing innovation delivering environmental benefits } \\
\text { along the production process (reduction in raw material use, reduction } \\
\text { of energy consumption, reduction of } \mathrm{CO}_{2} \text { emissions, substitution of } \\
\text { polluting raw materials or hazardous products, reduction of soil, water, } \\
\text { or air pollution, and recycling of waste, water, or raw materials) } \\
\text { (Continuous variable) }\end{array}$ & 2.13 & 2.30 & 0.00 & 6.00 \\
\hline \multicolumn{6}{|c|}{ Main explanatory variable } \\
\hline$E M P$ & $\begin{array}{l}\text { The firm has invested in procedures to regularly identify and reduce its } \\
\text { environmental impacts (e.g., preparing environmental audits, setting } \\
\text { environmental performance goals, ISO } 14001 \text { certification, etc.) } \\
\text { Dummy variable (=1 if yes before } 2006)\end{array}$ & 0.34 & 0.37 & 0.00 & 1.00 \\
\hline$E M P^{*} G R O W T H$ & $\begin{array}{l}E M P \text { when the market is growing (demean value) } \\
\text { (Continuous variable) }\end{array}$ & 0.03 & 0.40 & -1.05 & 0.95 \\
\hline$E M P^{*} U N C E R T A I N T Y$ & $\begin{array}{l}E M P \text { when the market is uncertain (demean value) } \\
\text { (Continuous variable) }\end{array}$ & 0.02 & 0.45 & -1.77 & 1.23 \\
\hline EMP*COMPETITION & $\begin{array}{l}E M P \text { when the market is strongly competitive (demean value) } \\
\text { (Continuous variable) }\end{array}$ & 0.02 & 0.49 & -1.36 & 1.63 \\
\hline \multicolumn{6}{|l|}{ Control variables } \\
\hline$S I Z E$ & $\begin{array}{l}\text { Number of employees } \\
\text { (Continuous variable) }\end{array}$ & 1965.397 & 5365.434 & 16.00 & 86520 \\
\hline$H O L D I N G$ & $\begin{array}{l}\text { Belonging to a holding group in } 2003 \\
\text { Dummy variable (=1 if yes) }\end{array}$ & 0.82 & 0.39 & 0.00 & 1.00 \\
\hline PROFIT & $\begin{array}{l}\text { The profit }(€) \text { in } 2003 \\
\text { (Continuous variable) }\end{array}$ & 8983.264 & 60731.32 & -520190 & 496874 \\
\hline CUTTING_COSTS & $\begin{array}{l}\text { Importance of cutting costs } \\
\text { (Continuous variable) }\end{array}$ & 3.32 & 0.65 & 1.00 & 4.00 \\
\hline$Q S$ & $\begin{array}{l}\text { Registration for the ISO } 9000 \text { standard in } 2003 . \\
\text { Dummy variable (=1 if registered) }\end{array}$ & 0.64 & 0.48 & 0.00 & 1.00 \\
\hline$R \& D$ & $\begin{array}{l}\text { The firm collaborated with private businesses or laboratories, the } \\
\text { National Centre for Scientific Research, universities or other public } \\
\text { bodies in research and development activities in } 2003 \\
\text { Dummy variable ( }=1 \text { if yes) }\end{array}$ & 0.37 & 0.48 & 0.00 & 1.00 \\
\hline CUSTOMER & $\begin{array}{l}\text { The firm used tools to study customers' expectations, behaviour or } \\
\text { satisfaction in } 2003 \\
\text { Dummy variable (=1 if yes) }\end{array}$ & 0.61 & 0.49 & 0.00 & 1.00 \\
\hline GROWTH & $\begin{array}{l}\text { How the market of the main activity of the firm has evolved since } 2003 \text { : } \\
\text { DOWN (=1 if yes) } \\
\text { STEADY (=2 if yes) } \\
\text { GROWING (=3 if yes) }\end{array}$ & 2.05 & 0.70 & 1.00 & 3.00 \\
\hline UNCERTAINTY & $\begin{array}{l}\text { Since } 2003 \text {, the firm has been affected very strongly or strongly by } \\
\text { uncertainty on the market } \\
\text { Dummy variable (=1 if yes) }\end{array}$ & 2.77 & 0.80 & 1.00 & 4.00 \\
\hline COMPETITION & $\begin{array}{l}\text { Since } 2003 \text {, the firm been affected very strongly or strongly by new } \\
\text { competitors on the market } \\
\text { Dummy variable (=1 if yes) }\end{array}$ & 2.36 & 0.81 & 1.00 & 4.00 \\
\hline
\end{tabular}
consumption goods, cars and equipments, intermediate goods, energy, construction, commercial, transport, financial and real-estate activities, business services and individual services, respectively)

\begin{tabular}{|c|c|c|c|c|c|}
\hline $\begin{array}{l}\text { RELOCATION } \\
\text { (Instrument) }\end{array}$ & $\begin{array}{l}\text { Relocation of a part of the business and implementation of new sites } \\
\text { abroad since } 2003 \\
\text { Dummy variable ( }=1 \text { if yes) }\end{array}$ & 0.11 & 0.31 & 0.00 & 1.00 \\
\hline $\begin{array}{l}\text { EXPORT } \\
\text { (Instrument) }\end{array}$ & $\begin{array}{l}\text { The share of exports of total sales }(€) \text { in } 2003 \\
\text { (Continuous variable) }\end{array}$ & 0.18 & 0.26 & 0.00 & 1.00 \\
\hline $\begin{array}{l}\text { GROWTH*RELOCATION } \\
\text { (Instrument) }\end{array}$ & $\begin{array}{l}\text { RELOCATION when the market is growing } \\
\text { (Continuous variable) }\end{array}$ & 0.23 & 0.70 & 0.00 & 3.00 \\
\hline $\begin{array}{l}\text { GROWTH*EXPORT } \\
\text { (Instrument) }\end{array}$ & $\begin{array}{l}\text { EXPORT when the market is growing } \\
\text { (Continuous variable) }\end{array}$ & 0.38 & 0.63 & 0.00 & 2.97 \\
\hline $\begin{array}{l}\text { UNCERTAINTY*RELOCATION } \\
\text { (Instrument) }\end{array}$ & $\begin{array}{l}\text { RELOCATION when the market is uncertain } \\
\text { (Continuous variable) }\end{array}$ & 0.31 & 0.94 & 0.00 & 4.00 \\
\hline $\begin{array}{l}\text { UNCERTAINTY*EXPORT } \\
\text { (Instrument) }\end{array}$ & $\begin{array}{l}\text { EXPORT when the market is uncertain } \\
\text { (Continuous variable) }\end{array}$ & 0.52 & 0.80 & 0.00 & 3.95 \\
\hline $\begin{array}{l}\text { COMPETITION*RELOCATION } \\
\text { (Instrument) }\end{array}$ & $\begin{array}{l}\text { RELOCATION when the market is strongly competitive } \\
\text { (Continuous variable) }\end{array}$ & 0.28 & 0.86 & 0.00 & 4.00 \\
\hline $\begin{array}{l}\text { COMPETITION*EXPORT } \\
\text { (Instrument) }\end{array}$ & $\begin{array}{l}\text { EXPORT when the market is strongly competitive } \\
\text { (Continuous variable) }\end{array}$ & 0.44 & 0.70 & 0.00 & 3.85 \\
\hline
\end{tabular}


Table 2: Definition of variables and sample statistics (sample for environmental innovations in the production stage)

\begin{tabular}{|c|c|c|c|c|c|}
\hline Variable & Description & Mean & SD & Min & Max \\
\hline \multicolumn{6}{|l|}{ Dependent variable } \\
\hline CONSENVINNO & $\begin{array}{l}\text { The firm has introduced between } 2006 \text { and } 2008 \text { a product, process, } \\
\text { organization or marketing innovation delivering environmental benefits } \\
\text { along the consumption process (reduction of energy use, reduction of } \\
\text { soil, water, or air pollution, and recycling of waste, water, or raw } \\
\text { materials) } \\
\text { (Continuous variable) }\end{array}$ & 0.82 & 1.18 & 0.00 & 3.00 \\
\hline \multicolumn{6}{|l|}{ Main explanatory variable } \\
\hline$E M P$ & $\begin{array}{l}\text { The firm has invested in procedures to regularly identify and reduce its } \\
\text { environmental impacts (e.g., preparing environmental audits, setting } \\
\text { environmental performance goals, ISO } 14001 \text { certification, etc.) } \\
\text { Dummy variable (=1 if yes before 2006) }\end{array}$ & 0.32 & 0.47 & 0.00 & 1.00 \\
\hline$E M P^{*} G R O W T H$ & $\begin{array}{l}E M P \text { when the market is growing (demean value) } \\
\text { (Continuous variable) }\end{array}$ & 0.04 & 0.40 & -1.01 & 0.98 \\
\hline EMP*UNCERTAINTY & $\begin{array}{l}E M P \text { when the market is uncertain (demean value) } \\
\text { (Continuous variable) }\end{array}$ & 0.03 & 0.44 & -1.78 & 1.22 \\
\hline EMP*COMPETITION & $\begin{array}{l}E M P \text { when the market is strongly competitive (demean value) } \\
\text { (Continuous variable) }\end{array}$ & 0.01 & 0.50 & -1.37 & 1.63 \\
\hline \multicolumn{6}{|l|}{ Control variables } \\
\hline SIZE & $\begin{array}{l}\text { Number of employees } \\
\text { (Continuous variable) }\end{array}$ & 2114.493 & 5923.964 & 16.00 & 55188 \\
\hline HOLDING & $\begin{array}{l}\text { Belonging to a holding group in } 2003 \\
\text { Dummy variable (=1 if yes) }\end{array}$ & 0.81 & 0.39 & 0.00 & 1.00 \\
\hline PROFIT & $\begin{array}{l}\text { The profit }(€) \text { in } 2003 \\
\text { (Continuous variable) }\end{array}$ & 8886.932 & 67991.06 & -520190 & 496874 \\
\hline CUTTING_COSTS & $\begin{array}{l}\text { Importance of cutting costs } \\
\text { (Continuous variable) }\end{array}$ & 3.32 & 0.65 & 1.00 & 4.00 \\
\hline$Q S$ & $\begin{array}{l}\text { Registration for the ISO } 9000 \text { standard in } 2003 . \\
\text { Dummy variable (=1 if registered) }\end{array}$ & 0.63 & 0.48 & 0.00 & 1.00 \\
\hline$R \& D$ & $\begin{array}{l}\text { The firm collaborated with private businesses or laboratories, the } \\
\text { National Centre for Scientific Research, universities or other public } \\
\text { bodies in research and development activities in } 2003 \\
\text { Dummy variable (=1 if yes) }\end{array}$ & 0.35 & 0.48 & 0.00 & 1.00 \\
\hline CUSTOMER & $\begin{array}{l}\text { The firm used tools to study customers' expectations, behaviour or } \\
\text { satisfaction in } 2003 \\
\text { Dummy variable ( }=1 \text { if yes) }\end{array}$ & 0.60 & 0.49 & 0.00 & 1.00 \\
\hline GROWTH & $\begin{array}{l}\text { How the market of the main activity of the firm has evolved since 2003: } \\
\text { DOWN (=1 if yes) } \\
\text { STEADY (=2 if yes) } \\
\text { GROWING (=3 if yes) }\end{array}$ & 2.01 & 0.70 & 1.00 & 3.00 \\
\hline UNCERTAINTY & $\begin{array}{l}\text { Since } 2003 \text {, the firm has been affected very strongly or strongly by } \\
\text { uncertainty on the market } \\
\text { Dummy variable (=1 if yes) }\end{array}$ & 2.78 & 0.81 & 1.00 & 4.00 \\
\hline COMPETITION & $\begin{array}{l}\text { Since } 2003 \text {, the firm been affected very strongly or strongly by new } \\
\text { competitors on the market } \\
\text { Dummy variable (=1 if yes) }\end{array}$ & 2.37 & 0.83 & 1.00 & 4.00 \\
\hline SECTOR & $\begin{array}{l}\text { Main activity of the firm. } 11 \text { dummy variables (=1 if agrifood, } \\
\text { consumption goods, cars and equipments, intermediate goods, energy, } \\
\text { construction, commercial, transport, financial and real-estate activities, } \\
\text { business services and individual services, respectively) }\end{array}$ & Because of & $\begin{array}{l}\text { table's len } \\
\text { istics for se }\end{array}$ & do not $r$ & sample \\
\hline $\begin{array}{l}\text { RELOCATION } \\
\text { (Instrument) }\end{array}$ & $\begin{array}{l}\text { Relocation of a part of the business and implementation of new sites } \\
\text { abroad since } 2003 \\
\text { Dummy variable ( }=1 \text { if yes) }\end{array}$ & 0.10 & 0.30 & 0.00 & 1.00 \\
\hline $\begin{array}{l}\text { EXPORT } \\
\text { (Instrument) }\end{array}$ & $\begin{array}{l}\text { The share of exports of total sales }(€) \text { in } 2003 \\
\text { (Continuous variable) }\end{array}$ & 0.17 & 0.26 & 0.00 & 1.00 \\
\hline $\begin{array}{l}\text { GROWTH*RELOCATION } \\
\text { (Instrument) }\end{array}$ & $\begin{array}{l}\text { RELOCATION when the market is growing } \\
\text { (Continuous variable) }\end{array}$ & 0.20 & 0.64 & 0.00 & 3.00 \\
\hline $\begin{array}{l}\text { GROWTH*EXPORT } \\
\text { (Instrument) }\end{array}$ & $\begin{array}{l}\text { EXPORT when the market is growing } \\
\text { (Continuous variable) }\end{array}$ & 0.36 & 0.63 & 0.00 & 2.97 \\
\hline $\begin{array}{l}\text { UNCERTAINTY*RELOCATION } \\
\text { (Instrument) }\end{array}$ & $\begin{array}{l}\text { RELOCATION when the market is uncertain } \\
\text { (Continuous variable) }\end{array}$ & 0.30 & 0.93 & 0.00 & 4.00 \\
\hline $\begin{array}{l}\text { UNCERTAINTY*EXPORT } \\
\text { (Instrument) }\end{array}$ & $\begin{array}{l}\text { EXPORT when the market is uncertain } \\
\text { (Continuous variable) }\end{array}$ & 0.49 & 0.78 & 0.00 & 3.95 \\
\hline $\begin{array}{l}\text { COMPETITION*RELOCATION } \\
\text { (Instrument) }\end{array}$ & $\begin{array}{l}\text { RELOCATION when the market is strongly competitive } \\
\text { (Continuous variable) }\end{array}$ & 0.27 & 0.84 & 0.00 & 4.00 \\
\hline $\begin{array}{l}\text { COMPETITION*EXPORT } \\
\text { (Instrument) }\end{array}$ & $\begin{array}{l}\text { EXPORT when the market is strongly competitive } \\
\text { (Continuous variable) }\end{array}$ & 0.41 & 0.69 & 0.00 & 3.84 \\
\hline
\end{tabular}


Table 3: 3SLS estimates of the relation between of EMPs and environmental innovations in the production stage when taking into account the moderating effect of market characteristics

\begin{tabular}{|c|c|c|c|c|c|}
\hline VARIABLES & $\begin{array}{c}\text { (1) } \\
\text { PRODENVINNO }\end{array}$ & $\begin{array}{c}(2) \\
E M P\end{array}$ & $\begin{array}{c}(3) \\
E M P * G R O W T H\end{array}$ & $\begin{array}{c}\text { (4) } \\
\text { EMP }^{*} U N C E R T A I N T Y\end{array}$ & $\begin{array}{c}(5) \\
\text { EMP*COMPETITION }\end{array}$ \\
\hline$E M P$ & $6.41 * * *(0.41)$ & - & - & - & - \\
\hline$E M P^{*} G R O W T H$ & $0.59 * * *(0.21)$ & - & - & - & - \\
\hline EMP*UNCERTAINTY & $-0.61 * * *(0.25)$ & - & - & - & - \\
\hline EMP*COMPETITION & $-1.26 * * *(0.21)$ & - & - & - & - \\
\hline SIZE & $0.00(0.00)$ & $0.00 * * *(0.00)$ & $0.00 *(0.00)$ & $0.00 * * *(0.00)$ & $0.00(0.00)$ \\
\hline HOLDING & $-0.39 * * *(0.10)$ & $0.11 * * *(0.02)$ & $0.02(0.02)$ & $-0.07 * * *(0.02)$ & $0.01(0.02)$ \\
\hline PROFIT & $-0.00 * * *(0.00)$ & $0.00 * * *(0.00)$ & $0.00 *(0.00)$ & $-0.00 * * *(0.00)$ & $0.00 * * *(0.00)$ \\
\hline CUTTING_COSTS & $-0.06(0.06)$ & $0.06 * * *(0.01)$ & $-0.01(0.01)$ & $0.05 * * *(0.01)$ & $0.07 * * *(0.01)$ \\
\hline$Q S$ & $-0.55 * * *(0.11)$ & $0.16 * * *(0.01)$ & $-0.03 * * *(0.01)$ & $-0.01(0.01)$ & $-0.04 * * *(0.02)$ \\
\hline$R \& D$ & $-0.19 * *(0.09)$ & $0.08 * * *(0.01)$ & $0.01(0.01)$ & $0.03 * * *(0.01)$ & $-0.05 * * *(0.02)$ \\
\hline CUSTOMER & $0.14 *(0.07)$ & $0.03 * * *(0.01)$ & $-0.01(0.01)$ & $0.00(0.01)$ & $-0.01(0.02)$ \\
\hline GROWTH & $-0.11(0.09)$ & $-0.01(0.01)$ & - & $-0.10 * * *(0.01)$ & $-0.04 * * *(0.01)$ \\
\hline UNCERTAINTY & $0.15 *(0.09)$ & $-0.03 * * *(0.01)$ & $-0.07 * * *(0.01)$ & - & $-0.00(0.01)$ \\
\hline COMPETITION & $0.23 * * *(0.09)$ & $-0.01(0.01)$ & $-0.01(0.01)$ & $0.01(0.01)$ & - \\
\hline AGRIFOOD & $0.01(0.16)$ & $-0.12 * * *(0.03)$ & $-0.05 * * *(0.02)$ & $0.05 *(0.03)$ & $0.07 * * *(0.03)$ \\
\hline CONSUMPTION & $0.67 * * *(0.17)$ & $-0.12 * * *(0.03)$ & $-0.01(0.03)$ & $0.00(0.03)$ & $0.14 * * *(0.03)$ \\
\hline CARS/EQUIPMENT & $-0.11(0.12)$ & $-0.06 * * *(0.02)$ & $-0.11 * * *(0.02)$ & $-0.02(0.02)$ & $-0.03(0.02)$ \\
\hline ENERGY & $-0.95 * * *(0.29)$ & $0.30 * * *(0.05)$ & $-0.07(0.04)$ & $-0.41 * * *(0.05)$ & $0.12 * * *(0.05)$ \\
\hline CONSTRUCTION & $0.35 *(0.18)$ & $0.05(0.03)$ & $0.19 * * *(0.03)$ & $0.18 * * *(0.03)$ & $0.12 * * *(0.04)$ \\
\hline COMMERCIAL & $1.16 * * *(0.18)$ & $-0.22 * * *(0.02)$ & $0.05 * * *(0.02)$ & $0.10 * * *(0.02)$ & $0.22 * * *(0.03)$ \\
\hline TRANSPORT & $0.61 * * *(0.18)$ & $-0.11 * * *(0.03)$ & $0.08 * * *(0.03)$ & $-0.04(0.03)$ & $0.18 * * *(0.03)$ \\
\hline $\begin{array}{l}\text { FINANCIAL/REAL } \\
\text { ESTATE }\end{array}$ & $1.75 * * *(0.27)$ & $-0.14 * * *(0.04)$ & $0.03(0.04)$ & $0.18 * * *(0.04)$ & $0.25 * * *(0.05)$ \\
\hline SERVICES_FIRMS & $0.95 * * *(0.18)$ & $-0.24 * * *(0.02)$ & $0.05 * * *(0.02)$ & $0.11 * * *(0.02)$ & $0.18 * * *(0.03)$ \\
\hline SERVICES_INDIV & $1.02 * * *(0.24)$ & $-0.18 * * *(0.04)$ & $0.09 * * *(0.04)$ & $0.09 * *(0.04)$ & $0.17 * * *(0.04)$ \\
\hline RELOCATION & - & $0.13 * * *(0.02)$ & - & - & - \\
\hline EXPORT & - & $0.40 * * *(0.03)$ & - & - & - \\
\hline GROWTH*RELOCATION & - & - & $0.06^{* * *}(0.01)$ & - & - \\
\hline GROWTH*EXPORT & - & - & $0.23 * * *(0.01)$ & - & - \\
\hline UNCERTAINTY*RELOCATION & $N$ & - & - & $0.05 * * *(0.01)$ & - \\
\hline UNCERTAINTY*EXPORT & - & - & - & $0.19 * * *(0.01)$ & - \\
\hline COMPETITION*RELOCATION & $N$ & - & - & - & $0.09 * * *(0.01)$ \\
\hline COMPETITION*EXPORT & - & - & - & - & $0.29 * * *(0.01)$ \\
\hline Constant & $-0.43(0.37)$ & $0.05(0.05)$ & $0.14 * * *(0.04)$ & $-0.07(0.05)$ & $-0.34 * * *(0.06)$ \\
\hline Observations & 4114 & 4114 & 4114 & 4114 & 4114 \\
\hline R-squared & -0.15 & 0.33 & 0.17 & 0.22 & 0.16 \\
\hline
\end{tabular}

$(*),(* *),(* * *)$ indicate parameter significance at the 10,5 and 1 per cent level, respectively. 
Table 4: 3SLS estimates of the relation between of EMPs and environmental innovations in the consumption stage when taking into account the moderating effect of market characteristics

\begin{tabular}{|c|c|c|c|c|c|}
\hline VARIABLES & $\begin{array}{c}\text { (1) } \\
\text { PRODENVINNO }\end{array}$ & $\begin{array}{c}(2) \\
E M P\end{array}$ & $\begin{array}{c}(3) \\
E M P * G R O W T H\end{array}$ & $\begin{array}{c}(4) \\
E M P * U N C E R T A I N T Y\end{array}$ & $\begin{array}{c}(5) \\
\text { EMP } * \text { COMPETITION }\end{array}$ \\
\hline$E M P$ & $3.62 * * *(0.25)$ & - & - & - & - \\
\hline$E M P^{*} G R O W T H$ & $-0.01(0.13)$ & - & - & - & - \\
\hline EMP*UNCERTAINTY & $-0.82 * * *(0.17)$ & - & - & - & - \\
\hline EMP*COMPETITION & $-0.86 * * *(0.13)$ & - & - & - & - \\
\hline SIZE & $0.00(0.00)$ & $0.00 * * *(0.00)$ & $0.00(0.00)$ & $0.00 * * *(0.00)$ & $0.00(0.00)$ \\
\hline HOLDING & $-0.16 * * *(0.06)$ & $0.08 * * *(0.02)$ & $0.02(0.02)$ & $-0.08 * * *(0.02)$ & $0.03(0.02)$ \\
\hline PROFIT & $-0.00 * * *(0.00)$ & $0.00 * * *(0.00)$ & $0.00 * * *(0.00)$ & $-0.00 * * *(0.00)$ & $0.00 * * *(0.00)$ \\
\hline CUTTING_COSTS & $-0.07 *(0.04)$ & $0.05 * * *(0.01)$ & $0.01(0.01)$ & $0.06 * * *(0.01)$ & $0.05 * * *(0.01)$ \\
\hline$Q S$ & $-0.23 * * *(0.06)$ & $0.14 * * *(0.02)$ & $-0.03 * *(0.02)$ & $-0.00(0.02)$ & $-0.05 * * *(0.02)$ \\
\hline$R \& D$ & $-0.24 * * *(0.06)$ & $0.11 * * *(0.02)$ & $-0.00(0.02)$ & $-0.01(0.02)$ & $-0.04 * *(0.02)$ \\
\hline CUSTOMER & $-0.02(0.05)$ & $0.03 *(0.02)$ & $-0.01(0.01)$ & $0.02(0.02)$ & $-0.02(0.02)$ \\
\hline GROWTH & $-0.15 * * *(0.05)$ & $0.01(0.01)$ & - & $-0.08 * * *(0.01)$ & $-0.05 * * *(0.01)$ \\
\hline UNCERTAINTY & $0.11 * *(0.05)$ & $-0.02(0.01)$ & $-0.06 * * *(0.01)$ & - & $-0.01(0.01)$ \\
\hline COMPETITION & $0.17 * * *(0.05)$ & $-0.01(0.01)$ & $-0.02 * * *(0.01)$ & $0.01(0.01)$ & - \\
\hline AGRIFOOD & $0.11(0.11)$ & $-0.15 * * *(0.03)$ & $-0.02(0.03)$ & $0.12 * * *(0.03)$ & $0.13 * * *(0.04)$ \\
\hline CONSUMPTION & $0.22 * *(0.10)$ & $-0.10 * * *(0.03)$ & $-0.02(0.03)$ & $0.04(0.03)$ & $0.12 * * *(0.04)$ \\
\hline CARS/EQUIPMENT & $0.17 * * *(0.08)$ & $-0.11 * * *(0.03)$ & $-0.12 * * *(0.03)$ & $-0.03(0.03)$ & $-0.15 * * *(0.03)$ \\
\hline ENERGY & $-0.91 * * *(0.19)$ & $0.27 * * *(0.06)$ & $-0.08(0.06)$ & $-0.36 * * *(0.06)$ & $-0.10(0.07)$ \\
\hline CONSTRUCTION & $0.24 * * *(0.11)$ & $0.07 *(0.04)$ & $0.18 * * *(0.03)$ & $0.14 * * *(0.04)$ & $0.13 * * *(0.04)$ \\
\hline COMMERCIAL & $0.68 * * *(0.10)$ & $-0.19 * * *(0.03)$ & $0.03(0.02)$ & $0.10 * * *(0.03)$ & $0.19 * * *(0.03)$ \\
\hline TRANSPORT & $0.14(0.11)$ & $-0.09 * * *(0.03)$ & $0.02(0.03)$ & $-0.03(0.03)$ & $0.20 * * *(0.04)$ \\
\hline FINANCIAL/REAL ESTATE & $1.21 * * *(0.17)$ & $-0.11 *(0.05)$ & $0.02(0.05)$ & $0.22 * * *(0.05)$ & $0.27 * * *(0.06)$ \\
\hline SERVICES_FIRMS & $0.51 * * *(0.10)$ & $-0.16 * * *(0.03)$ & $0.03(0.03$ & $0.08 * * *(0.03)$ & $0.13 * * *(0.03)$ \\
\hline SERVICES_INDIV & $0.15(0.14)$ & $-0.10 * * *(0.04)$ & $0.10 * * *(0.04)$ & $0.08 *(0.05)$ & $0.14 * * *(0.05)$ \\
\hline RELOCATION & - & $0.15 * * *(0.02)$ & - & - & - \\
\hline EXPORT & - & $0.41 * * *(0.04)$ & - & - & - \\
\hline GROWTH*RELOCATION & - & - & $0.04 * * *(0.01)$ & - & - \\
\hline GROWTH*EXPORT & - & - & $0.25 * * *(0.01)$ & - & - \\
\hline UNCERTAINTY*RELOCATION & - & - & - & $0.05 * * *(0.01)$ & - \\
\hline UNCERTAINTY*EXPORT & - & - & - & $0.18 * * *(0.01)$ & - \\
\hline COMPETITION*RELOCATION & - & - & - & - & $0.10 * * *(0.01)$ \\
\hline COMPETITION* ${ }^{*}$ EXORT & - & - & - & - & $0.30 * * *(0.01)$ \\
\hline Constant & $-0.40 *(0.23)$ & $-0.02(0.06)$ & $0.09 *(0.05)$ & $-0.15 * * *(0.05)$ & $-0.25 * * *(0.07)$ \\
\hline Observations & 2816 & 2816 & 2816 & 2816 & 2816 \\
\hline R-squared & -0.42 & 0.33 & 0.17 & 0.22 & 0.17 \\
\hline
\end{tabular}

$(*),(* *),(* * *)$ indicate parameter significance at the 10,5 and 1 per cent level, respectively. 




\begin{tabular}{|c|c|c|c|c|c|c|c|c|c|c|c|c|c|c|c|c|c|c|c|c|c|c|c|}
\hline & 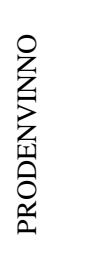 & $\underset{1}{\$}$ & 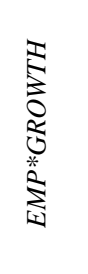 & 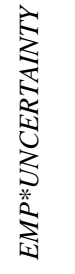 & 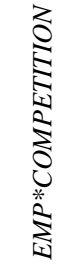 & $\stackrel{N}{N}$ & 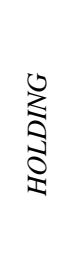 & $\begin{array}{l}\mathbb{z} \\
0 \\
\approx \\
\alpha\end{array}$ & 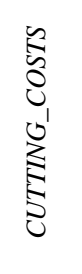 & $a$ & $\underset{\approx}{\approx}$ & 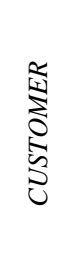 & 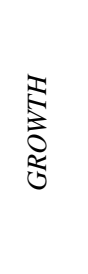 &  & 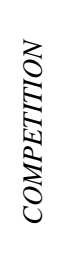 & 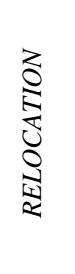 &  &  &  & 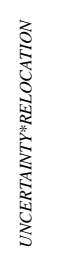 & 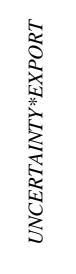 &  & 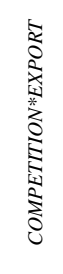 \\
\hline PRODENVINNO & 1.00 & - & - & - & - & - & - & - & - & - & - & - & - & - & - & - & - & - & - & - & - & - & - \\
\hline$E M P$ & 0.58 & 1.00 & - & - & - & - & - & - & - & - & - & - & - & - & - & - & - & - & - & - & - & - & - \\
\hline EMP*GROWTH & 0.12 & 0.09 & 1.00 & - & - & - & - & - & - & - & - & - & - & - & - & - & - & - & - & - & - & - & - \\
\hline EMP*UNCERTAINTY & 0.04 & 0.07 & -0.29 & 1.00 & - & - & - & - & - & - & - & - & - & - & - & - & - & - & - & - & - & - & - \\
\hline EMP $^{*}$ COMPETITION & 0.03 & 0.05 & $\begin{array}{c}-0.02 \\
\end{array}$ & 0.27 & 1.00 & - & - & - & - & - & - & - & - & - & - & - & - & - & - & - & - & - & - \\
\hline SIZE & 0.17 & 0.14 & 0.03 & 0.17 & 0.02 & 1.00 & - & - & - & - & - & - & - & - & - & - & - & - & - & - & - & - & - \\
\hline HOLDING & 0.14 & 0.21 & 0.05 & -0.02 & 0.06 & 0.01 & 1.00 & - & - & - & - & - & - & - & - & - & - & - & - & - & - & - & - \\
\hline$\overline{P R O F I T}$ & 0.04 & 0.07 & 0.04 & -0.10 & 0.02 & 0.17 & 0.03 & 1.00 & - & - & - & - & - & - & - & - & - & - & - & - & - & - & - \\
\hline CUTTING_COSTS & 0.17 & 0.23 & 0.01 & 0.16 & 0.15 & 0.10 & 0.15 & -0.06 & 1.00 & - & - & - & - & - & - & - & - & - & - & - & - & - & - \\
\hline$Q S$ & 0.26 & 0.39 & 0.04 & 0.08 & 0.03 & 0.10 & 0.21 & 0.02 & 0.18 & 1.00 & - & - & - & - & - & - & - & - & - & - & - & - & - \\
\hline$R \& D$ & 0.25 & 0.31 & 0.07 & 0.14 & 0.06 & 0.15 & 0.12 & 0.05 & 0.14 & 0.30 & 1.00 & - & - & - & - & - & - & - & - & - & - & - & - \\
\hline CUSTOMER & 0.18 & 0.16 & 0.01 & 0.04 & 0.02 & 0.13 & 0.15 & 0.04 & 0.08 & 0.17 & 0.30 & 1.00 & - & - & - & - & - & - & - & - & - & - & - \\
\hline GROWTH & 0.09 & 0.08 & 0.58 & -0.17 & $\begin{array}{l}-0.01 \\
\end{array}$ & 0.03 & 0.01 & 0.05 & -0.02 & 0.10 & 0.08 & 0.02 & 1.00 & - & - & - & - & - & - & - & - & - & - \\
\hline UNCERTAINTY & 0.03 & 0.06 & -0.17 & 0.57 & 0.16 & 0.10 & 0.02 & $\begin{array}{c}-0.04 \\
\end{array}$ & 0.23 & 0.09 & 0.17 & 0.09 & $\begin{array}{l}-0.24 \\
\end{array}$ & 1.00 & & - & - & - & - & - & - & - & - \\
\hline COMPETITION & 0.03 & 0.04 & -0.01 & 0.16 & 0.61 & 0.03 & 0.07 & 0.02 & 0.19 & 0.03 & 0.09 & 0.06 & -0.05 & 0.30 & 1.00 & & - & - & - & - & - & - & - \\
\hline RELOCATION & 0.17 & 0.20 & 0.06 & 0.08 & 0.13 & -0.01 & 0.11 & -0.02 & 0.15 & 0.15 & 0.12 & 0.07 & 0.05 & 0.08 & 0.12 & 1.00 & - & - & - & - & - & - & - \\
\hline EXPORT & 0.32 & 0.42 & 0.11 & 0.15 & 0.08 & 0.05 & 0.15 & -0.00 & 0.24 & 0.34 & 0.38 & 0.11 & 0.11 & 0.15 & 0.08 & 0.22 & 1.00 & & - & - & - & - & - \\
\hline GROWTH*RELOCATION & 0.16 & 0.20 & 0.18 & 0.06 & 0.13 & -0.00 & 0.10 & -0.02 & 0.14 & 0.16 & 0.12 & 0.07 & 0.16 & 0.06 & 0.11 & 0.10 & 0.23 & 1.00 & - & - & - & - & - \\
\hline GROWTH*EXPORT & 0.32 & 0.39 & 0.30 & 0.09 & 0.06 & 0.06 & 0.14 & 0.02 & 0.21 & 0.31 & 0.36 & 0.09 & 0.29 & 0.10 & 0.05 & 0.22 & 0.94 & 0.27 & 1.00 & - & - & - & - \\
\hline UNCERTAINTY*RELOCATION & 0.17 & 0.19 & 0.05 & 0.16 & 0.14 & -0.01 & 0.11 & -0.02 & 0.16 & 0.14 & 0.11 & 0.08 & 0.03 & 0.16 & 0.14 & 0.10 & 0.21 & 0.89 & 0.21 & 1.00 & - & - & - \\
\hline UNCERTAINTY*EXPORT & 0.30 & 0.41 & 0.07 & 0.31 & 0.14 & 0.08 & 0.14 & -0.04 & 0.25 & 0.34 & 0.39 & 0.10 & 0.07 & 0.31 & 0.12 & 0.21 & 0.95 & 0.22 & 0.88 & 0.23 & 1.00 & - & - \\
\hline COMPETITION *RELOCATION & 0.16 & 0.20 & 0.07 & 0.10 & 0.22 & -0.01 & 0.11 & -0.05 & 0.16 & 0.14 & 0.11 & 0.07 & 0.04 & 0.10 & 0.21 & 0.95 & 0.21 & 0.89 & 0.20 & 0.94 & 0.21 & 1.00 & - \\
\hline COMPETITION*EXPORT & 0.28 & 0.39 & 0.08 & 0.21 & 0.32 & 0.01 & 0.15 & -0.03 & 0.25 & 0.32 & 0.35 & 0.08 & 0.08 & 0.19 & 0.31 & 0.23 & 0.91 & 0.24 & 0.84 & 0.23 & 0.90 & 0.26 & 1.00 \\
\hline
\end{tabular}




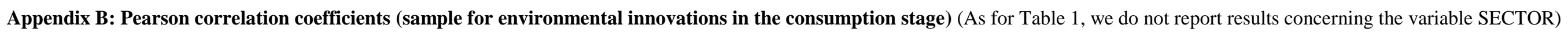

\begin{tabular}{|c|c|c|c|c|c|c|c|c|c|c|c|c|c|c|c|c|c|c|c|c|c|c|c|}
\hline & 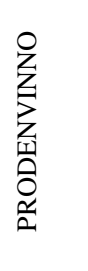 & $\underset{i=1}{\$}$ &  & 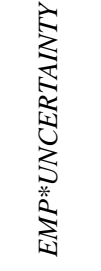 & 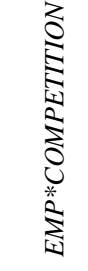 & 袋 & $\begin{array}{l}0 \\
\vdots \\
\vdots \\
0 \\
0\end{array}$ & $\begin{array}{l}\mathbb{v} \\
0 \\
2 \\
2\end{array}$ & 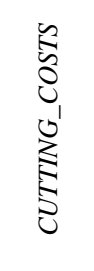 & $\tilde{a}$ & $\underset{\approx}{\approx}$ & 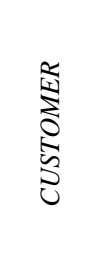 & 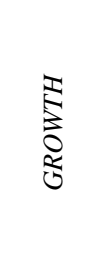 &  & 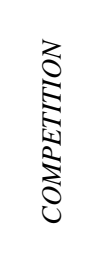 & 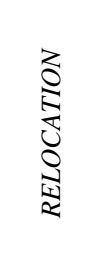 & 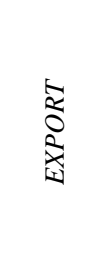 & 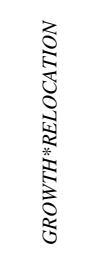 &  & 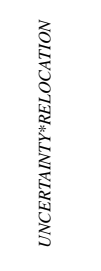 &  & 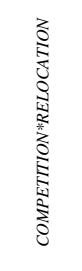 & 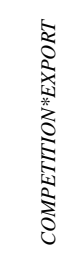 \\
\hline PRODENVINNO & 1.00 & - & - & - & - & - & - & - & - & - & - & - & - & - & - & - & - & - & - & - & - & - & - \\
\hline$E M P$ & 0.57 & 1.00 & - & - & - & - & - & - & - & - & - & - & - & - & - & - & - & - & - & - & - & - & - \\
\hline EMP*GROWTH & 0.05 & 0.14 & 1.00 & - & - & - & - & - & - & - & - & - & - & - & - & - & - & - & - & - & - & - & - \\
\hline EMP*UNCERTAINTY & 0.08 & 0.09 & -0.28 & 1.00 & - & - & - & - & - & - & - & - & - & - & - & - & - & - & - & - & - & - & - \\
\hline EMP $^{*}$ COMPETITION & $\begin{array}{c}-0.03 \\
\end{array}$ & 0.03 & -0.06 & 0.29 & 1.00 & - & - & - & - & - & - & - & - & - & - & - & - & - & - & - & - & - & - \\
\hline $\begin{array}{l}\text { SIZE } \\
\end{array}$ & 0.20 & 0.18 & 0.04 & 0.22 & 0.02 & 1.00 & - & - & - & - & - & - & - & - & - & - & - & - & - & - & - & - & - \\
\hline HOLDING & 0.12 & 0.18 & 0.05 & $\begin{array}{c}-0.03 \\
\end{array}$ & 0.07 & -0.01 & 1.00 & - & - & - & - & - & - & - & - & - & - & - & - & - & - & - & - \\
\hline$\overline{P R O F I T}$ & 0.06 & 0.08 & 0.06 & -0.05 & 0.10 & 0.17 & 0.03 & 1.00 & - & - & - & - & - & - & - & - & - & - & - & - & - & - & - \\
\hline CUTTING_COSTS & 0.13 & 0.21 & 0.05 & 0.19 & 0.12 & 0.10 & 0.15 & -0.05 & 1.00 & - & - & - & - & - & - & - & - & - & - & - & - & - & - \\
\hline$Q S$ & 0.28 & 0.37 & 0.06 & 0.08 & 0.01 & 0.10 & 0.21 & 0.02 & 0.14 & 1.00 & - & - & - & - & - & - & - & - & - & - & - & - & - \\
\hline$R \& D$ & 0.25 & 0.35 & 0.09 & 0.12 & 0.04 & 0.17 & 0.14 & 0.07 & 0.15 & 0.31 & 1.00 & - & - & - & - & - & - & - & - & - & - & - & - \\
\hline CUSTOMER & 0.15 & 0.17 & 0.01 & 0.07 & 0.00 & 0.13 & 0.15 & 0.04 & 0.08 & 0.18 & 0.31 & 1.00 & - & - & - & - & - & - & - & - & - & - & - \\
\hline GROWTH & 0.06 & 0.12 & 0.57 & -0.15 & -0.03 & 0.03 & 0.01 & 0.04 & -0.03 & 0.11 & 0.07 & 0.01 & 1.00 & - & - & - & - & - & - & - & - & - & - \\
\hline UNCERTAINTY & 0.04 & 0.07 & $\begin{array}{ll}-0.14 \\
\end{array}$ & 0.54 & 0.16 & 0.13 & 0.02 & 0.00 & 0.24 & 0.07 & 0.05 & 0.11 & $\begin{array}{l}-0.23 \\
\end{array}$ & 1.00 & - & - & - & - & - & - & - & - & - \\
\hline COMPETITION & -0.01 & 0.02 & 0.04 & 0.17 & 0.59 & 0.05 & 0.09 & 0.07 & 0.18 & 0.01 & 0.10 & 0.05 & -0.06 & 0.32 & 1.00 & - & - & - & - & - & - & - & - \\
\hline RELOCATION & 0.16 & 0.20 & 0.00 & 0.09 & 0.14 & -0.02 & 0.11 & 0.01 & 0.17 & 0.13 & 0.11 & 0.10 & -0.01 & 0.08 & 0.12 & 1.00 & - & - & - & - & - & - & - \\
\hline EXPORT & 0.30 & 0.42 & 0.15 & 0.15 & 0.05 & 0.07 & 0.14 & 0.00 & 0.22 & 0.34 & 0.39 & 0.11 & 0.14 & 0.13 & 0.05 & 0.21 & 1.00 & - & - & - & - & - & - \\
\hline GROWTH*RELOCATION & 0.15 & 0.21 & 0.12 & 0.08 & 0.16 & -0.02 & 0.10 & 0.01 & 0.16 & 0.15 & 0.12 & 0.09 & 0.11 & 0.07 & 0.12 & 0.94 & 0.21 & 1.00 & - & - & - & - & - \\
\hline GROWTH*EXPORT & 0.28 & 0.39 & 0.34 & 0.10 & 0.03 & 0.07 & 0.13 & 0.03 & 0.19 & 0.31 & 0.36 & 0.09 & 0.31 & 0.08 & 0.04 & 0.18 & 0.94 & 0.23 & 1.00 & - & - & - & - \\
\hline UNCERTAINTY*RELOCATION & 0.16 & 0.20 & -0.00 & 0.16 & 0.14 & -0.03 & 0.11 & 0.02 & 0.17 & 0.12 & 0.09 & 0.10 & $\begin{array}{c}-0.02 \\
\end{array}$ & 0.16 & 0.13 & 0.96 & 0.18 & 0.89 & 0.15 & 1.00 & - & - & - \\
\hline UNCERTAINTY*EXPORT & 0.29 & 0.42 & 0.12 & 0.30 & 0.10 & 0.10 & 0.13 & -0.03 & 0.23 & 0.34 & 0.39 & 0.11 & 0.10 & 0.27 & 0.09 & 0.18 & 0.96 & 0.20 & 0.89 & 0.19 & 1.00 & - & - \\
\hline COMPETITION *RELOCATION & 0.16 & 0.20 & 0.02 & 0.09 & 0.21 & -0.03 & 0.11 & 0.00 & 0.17 & 0.12 & 0.09 & 0.07 & -0.01 & 0.09 & 0.19 & 0.96 & 0.18 & 0.90 & 0.16 & 0.94 & 0.18 & 1.00 & - \\
\hline COMPETITION $^{*}$ EXPORT & 0.24 & 0.39 & 0.12 & 0.20 & 0.30 & 0.01 & 0.14 & -0.00 & 0.22 & 0.31 & 0.35 & 0.07 & 0.12 & 0.17 & 0.29 & 0.21 & 0.91 & 0.23 & 0.85 & 0.20 & 0.90 & 0.23 & 1.00 \\
\hline
\end{tabular}

